\title{
Development of Android-Based Software to Support the Selection of University Majors that Fits with Student Personality Type
}

\author{
Fridayanti ${ }^{1}$, Wisnu Uriawan ${ }^{\star 2}$, Aldy Rialdy Atmadja ${ }^{3}$ \\ ${ }^{1}$ Sunan Gunung Djati Bandung, Indonesia/Psychology DepartmentUIN \\ 2,35unan Gunung Djati Bandung, Indonesia/Informatics DepartmentUIN \\ fridayanti@uinsgd.ac.id¹ ${ }^{1}$,wisnu_u@uinsgd.ac.id², aldy@if.uinsgd.ac.id ${ }^{3}$
}

\begin{abstract}
Selecting study program is important things that must decide for high school student in Indonesia. However, students often have difficulties to explore the field of study which match with him. Technology can be used as a tool for making a decision, for example by using android application. Android platform has advantages because it is easy to accessible and familiar in teenagers in Indonesia. In this research, an application was developed by Rational Unified Process methodology. The selection of study program is done with knowing personality type. There are 6 criteria in defining personality type with RIASEC method: Realistic, Investigative, Artistic, Social, Enterprising, Conventional. Personality type can be known after user filled the questionnaire in an application. Next, an application can display study program that matches the type of user personality. From evaluation and analysis, the result showed that application is easy to use. It is expected that this application can be a simulated application which provides information and solutions in advance to selecting study program in universities.
\end{abstract}

Keywords: DSS, RUP, Android, Hollad Theory, RIASEC

\section{Introduction}

Choosing a study program is an important decision-making for almost high school students in Indonesia. Students must choose several alternative courses for further study at the college level. Student must have decision before they graduated because all of Indonesia students must follow an examination to be selected as college student from state universities. Thus, high school student should decide the best option from several universities. The decision in choosing the right course of study will be the key to success in the future. On the other hand, it is often found student have less information about alternative courses of study. Accordingly, it makes difficult to choose the right decision for high all of school students in Indonesia.

The problem of student who have difficulty in choosing his study is the lack of information. Actually, the information of study program has been widely spread through web page from universities. Many study program in Indonesia has same name but there are on different faculties, including the description of courses that have similarities in the naming. So, students are often difficult to obtain the right information because this information is very important to avoid mistakes in selecting courses.

Now, Information Technology has growed rapidly and needs to be developed in order to bring benefits and aspects of life. Psyschology and career guidance can take advantage of developing technology that help and provide information for high schoool students to choiece courses in college. Decision Support system is one of technology that can assist in supporting decisions to improve the effectiveness of decision makers in solving semi-structured or unstructured problems. Therefore, the purpose of this study is to make a decision support system (DSS) for election study program.

There are many researches on decision support system to select study program and have diverse criteria. First, Yuda Setiawan has developed decision support system to help people that choose study program in STAIN Kediri with some of criteria, such as the number of applicants, accreditation and GPA score. But this research only implemented in a local area [1]. Another type of research which also has similar scope is a research who developed by Yusditia, Imrona, and Damayanti. On this research, decision support system has using school lessons as a criteria. Study program also has provide many universities and college in Java Island. Wirastama has

Fridayanti, F., Uriawan, W., \& Atmadja, A. (2018). Development of Android-Based Software to Support The Selection of University Majors that Fits with Student Personality Type. Kinetik: Game Technology, Information System, Computer Network, Computing, Electronics, and Control, 3(3). doi:http://dx.doi.org/10.22219/kinetik.v3i3.628

Receive March 15, 2018; Revise March 26, 2018; Accepted April 16, 2018 
done his research with many parameter such as study program, interest, parents background, ideal and tuition fee from many universities. This research has onlhy developed for specific courses like ecomonic, law, computer science and medical. This research has implemented diverse criteria and aspect of interest [2]. Alwanuha also has same idea, the research used decision support system based on this criteria like lesson score, abilities and interests. Area of interest depends on skills to operate electronic tools, computer, and music. The results showed that the study not used type of personality as a criteria like Holland theory. On a broader scale, Holland Code is one of the theories that researchers use to help the course selection, one at the University of Miami [3].

These research focused on designing Decision Support System based on student personality type by using a questionnaire of the RIASEC personality type which developed based on John Holland's Theory. The criteria is chosen because this personality type is one of the widely used theories for choosing a course of study. In Indonesia, this criterion has not been developed as a general criteria for selection of study program. Several universities are being a target to developed for this research such as Universitas Indonesia, Universitas Padjajaran, Universitas Gadjah Mada, UIN Sunan Gunung Djati and Universitas Pendidikan Indonesia. This study has impelement as an android-based application system that will be installed on smartphone to help people to used easily and search information quickly. Through this research is expected to get adequate information to assist students in determining courses in college. This research is expected to get adequate information for assisting students in determining courses in college.

\section{Research Method}

\subsection{Holland Personality Type}

John L Holland is an influential psychologist and being one of the most influential in personality studies and selection of courses and careers. The theory is also known as The personal-environment fit. He made postulates that students would get better results when they choose an Education course that fit on their personality orientation [4]. There are two components such as psychological and sociological components [5].

Pyschological/ individual component in Holland's Theory assumes that the choice of major in study program is an expression of personality type and can be classified into six personality types, which consists of Realistic, Investigate, Artistic, Social, Enterprising and Conventional [6].

This personality type are often abbreviated as RIASEC, so people also known as RIASEC personality type. Each person has unique characteristics and can have one or more this personality type. However, every person hava a dominant or secondary characteristic. In this research, personal characteristics sorted by level of domination. As an example, people who have RSI type, it means this person have dominant type in realistic, social and investigate. To define the likelihood personality can be taken from two or three dominant characteristics of a person [3] [7] [8].

Educational environment and sociology can be complied into the RIASEC system. Thus, the model can fit the existing personality model. So that, the context of study programs, career and work can be classified also based on the RIASEC type [7].

\subsection{Decision Support System}

Decision Support System are known as DSS, was first introduced by Scoot Morton in the 1970s. Morton describes a decision support system as an interactive computer-based system that support decision makers by using data and models to solve unstructured problems [9]. DSS can be regarded as the third generation of computer-based applications. [10].

This system was originally intended to be a tool for decision makers to expand their ability to make decisions. The system was not developed to replace the assessment, but to improve the effectiveness of a decision.

In this paper, decision system are developer for selection university major. This system are expected to assist counseling teachers in giving guidance to choose majors in advanced study in college. Decision system also provide assistance to students and can explore themselves before making a decision about the course.

\subsection{Android-Based Decision Support System}

Android id an operating system for mobile devices based on Linux platform. Android provides an open platform for developers to create applications that can be used on various types

KINETIK Vol. 3, No. 3, August 2018: 203-212 
of mobile phones. Today, decision support system are widely developed in the android application. Android-based decision support system have an advantage, such as the ease of input basic knowledge that can be done anywhere and anytime. It makes a treasury of knowledge on android application decision support system becomes more complete. Android based system is freely available for commercial and non-commercial use because android is an open platform for developers to create applications. This system has the advantage of being computer code-based software that can be distributed openly, so that programmers can create new applications in it.

\subsection{Rational Unified Process}

In this research, Rational Unified Process (RUP) are used to build system methodology.

There are four steps in implementing Rational Unified Process [11]:

1. Inception

Inception is one of the analysis steps, where some activities are conducted to identify the user needs and perform the initial design of the device or application to be built.

2. Elaboration

In this stage, the design phase has been done with protoytype of application has been created. The result of this phase based on the inception phase on previous stage. This stage begins by specifying software features until the prototype release of the software.

3. Construction

On this contruction phase, the application has done and suitable in personality type and choices of study program.

4. Transition

On this transititin phase, there are some steps such as install application on devices, testing, deployment and dissemintaion software. Evaluation also have done in transition phase to ensure appropriate user needs after testing has been finished.

\section{Results and Discussion}

\subsection{Problem Analysis}

Specialization tests and talents can often be found in schools or professional institution. Both of test are done by a psychologists. In fact, the technology has changed the way to do the test dan the format can be accesible by users in everywhere. So, the technology certainly helps students in evaluating the test results of his interest, talent and expertise.

\subsection{Requirement Analysis}

\subsubsection{User Interface Requirements}

People can access the application with an interface. To operate android application, people should use smartphone, tab or other device with Android Operating System. This application connect with database to help making judgement from the results and asessment of interest and talent test.

\subsubsection{Functional Requirements}

Based on the results of the analysis of interest and talent test patterns and definitions for the needs of mobile application development, some functional requirements are generated in Table 1.

Table 1. Functional Requirements

\begin{tabular}{cll}
\hline ID & \multicolumn{1}{c}{ Requirements } & \multicolumn{1}{c}{ Explanation } \\
\hline FR-01 & $\begin{array}{l}\text { Applications can test interest and } \\
\text { talent } \\
\text { Applications can perform } \\
\text { assessments of interest and talent } \\
\text { tests }\end{array}$ & $\begin{array}{l}\text { After installing the application, users } \\
\text { are allowed to do the test } \\
\text { The system can perform expert } \\
\text { assessment of the tests performed by } \\
\text { the user }\end{array}$ \\
FR-02 & $\begin{array}{l}\text { Users can view a history of all tests that } \\
\text { have been done by the users along } \\
\text { with the conclusions of the results of } \\
\text { tests conducted }\end{array}$ \\
\hline
\end{tabular}




\subsubsection{Non-Functional Requirements}

Based on the the analysis of interest and talent test patterns and excavations for the needs of mobile application development, resulting in several non-functional requirements. The requirements are showed in the following Table 2.

Table 2. Non-Functional Requirements

\begin{tabular}{|c|c|c|}
\hline ID & Requirements & Explanation \\
\hline NFR- 01 & Availability & Applications must be usable with $99 \%$ uptime \\
\hline NFR- 02 & Reliability & $\begin{array}{l}\text { In the event of interruption, the application must } \\
\text { be restart easily }\end{array}$ \\
\hline NFR- 03 & Portability & Application based on android platform \\
\hline NFR- 04 & Response time & $\begin{array}{l}\text { The app gives a maximum response time of } 2 \\
\text { seconds. }\end{array}$ \\
\hline NFR- 05 & Security & $\begin{array}{l}\text { Applications can ensure the confidentiality of } \\
\text { managed data }\end{array}$ \\
\hline NFR- 06 & Language & Application use Indonesian Language \\
\hline
\end{tabular}

\subsection{Designing System}

\subsubsection{Use Case Diagram}

Based on the analysis on the functional requirements then obtained use case as follows Table 3, where there is one actor involved the user only. Users can test interest and talent, see the history test results of interest and talent. The system performs readings on the tests the user conducts to assess the test results.

Table 3. Actor in Use Case Diagram

\begin{tabular}{cc}
\hline Actor & Definition \\
\hline User & $\begin{array}{l}\text { Users can test interest and talent using two different models. There are } \\
\text { general test model and professional test model. Assessment is done } \\
\text { based on the expert system to see the results of tests performed. }\end{array}$ \\
\hline
\end{tabular}

In the following Figure 1. Use Case Diagram can be showed to know the scope of application that has been developed.

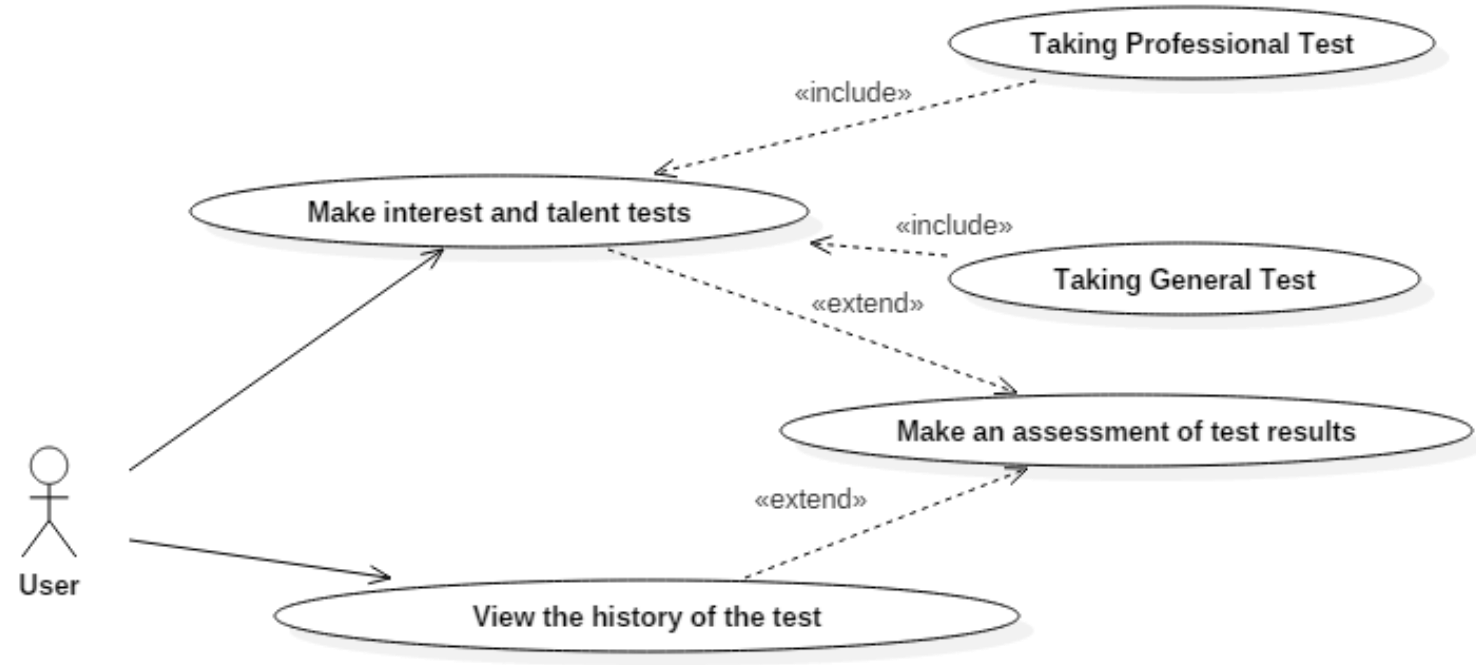

Figure 1. Use Case Diagram

There is an explanation of each use case as described in the above picture. The explanatory details of each use case are described in the following Table 4. 
Table 4. Definition of Use Case Diagram

\begin{tabular}{|c|c|c|}
\hline No & Use Case & Definition \\
\hline 1. & Make interest and talent tests & $\begin{array}{l}\text { Use case where users can test interest and } \\
\text { talent }\end{array}$ \\
\hline 2. & Taking General Test & $\begin{array}{l}\text { This use case is one part of the interest and } \\
\text { talent test where the method used for General } \\
\text { Test }\end{array}$ \\
\hline 3. & Taking Professional Test & $\begin{array}{l}\text { This use case is one part of the interest and } \\
\text { talent test where the method used for } \\
\text { ProfessionalTest }\end{array}$ \\
\hline 4. & $\begin{array}{c}\text { Make an assessment of test } \\
\text { results }\end{array}$ & $\begin{array}{l}\text { Use case where the assessment process by } \\
\text { expert system is done, the output is } \\
\text { recommendation of department choice and } \\
\text { user interest }\end{array}$ \\
\hline 5. & View the history of the test & $\begin{array}{l}\text { Use case to view history of interest and talent } \\
\text { tests that have been done }\end{array}$ \\
\hline
\end{tabular}

\subsubsection{Class Diagram}

In the next figure, class diagram showed the design of class dlass diagram for an android psychology application. The class diagram is illustrated in the Figure 2.

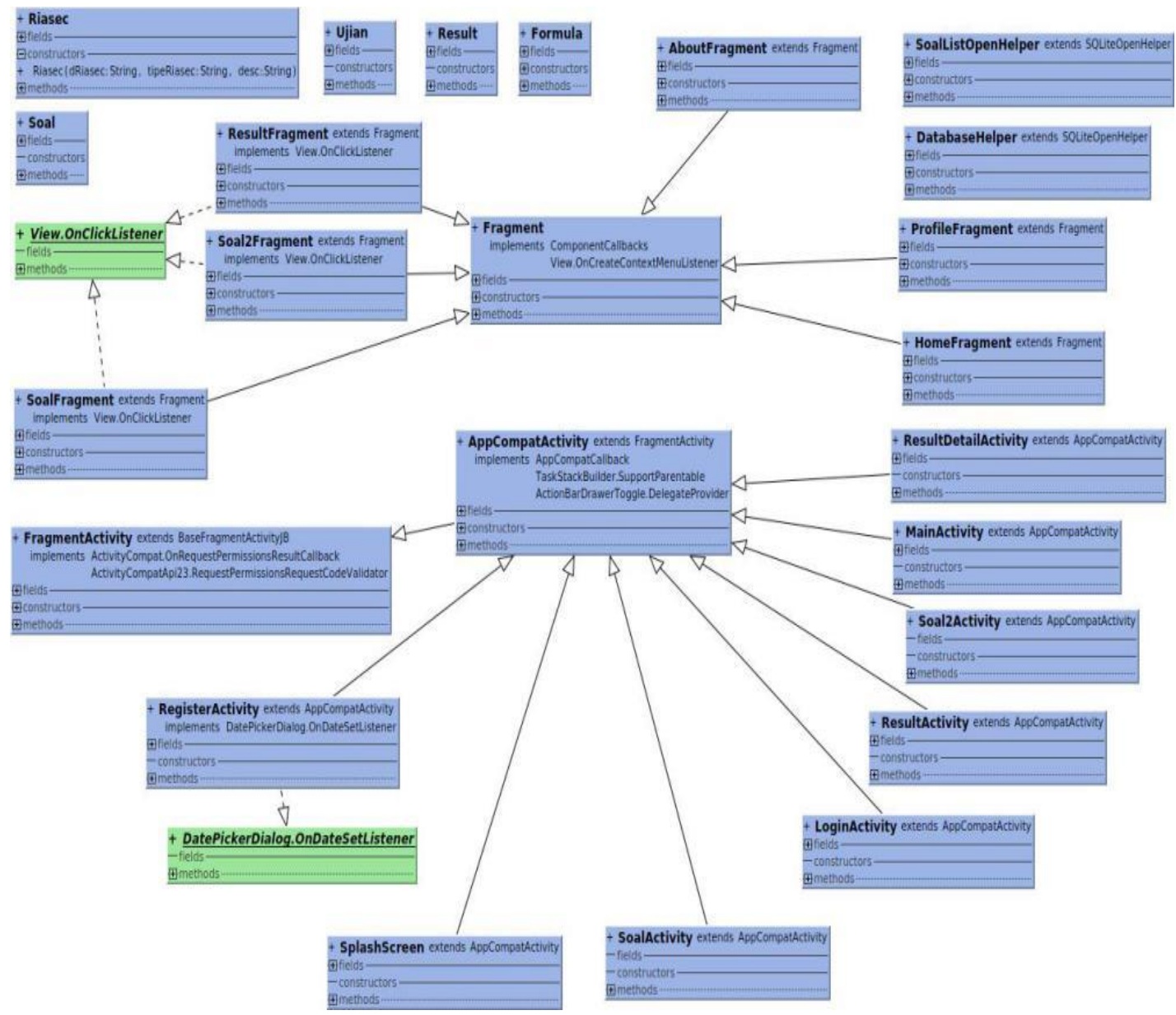

Figure 2. Class Diagram

This section explain the results of research and at the same time is given the comprehensive discussion. Results can be presented in figures, graphs, tables and others that make the reader understand easily [12]. The discussion can be made in several sub-sections. 


\subsection{System Implementation}

\subsubsection{Preparing Instalation}

Implementation phase of this system is the stage of putting the system ready for operation. There are several stages of implementation that must be implemented include the preparation of software software and hardware. Android Studio is one of the tools to support the performance of Android OS apps. As for the hardware required: Mobile Device with Android Operating System, and the specifications are:

1. Operating System: Android 2.3.6

2. CPU: $1 \mathrm{GHz}$ Processor

3. RAM: 2 GB.

4. In this application require specifications: Operating System (Client): Android Mobile Device with minimum OS version 4.1 (Jelly Bean) and using SQLite as Database Management System (local database).

\subsubsection{Implementation}

This page is the first page that appears before the main page, where there is a logo of the application. Figure 3 shows the appearance of Splash Screen.

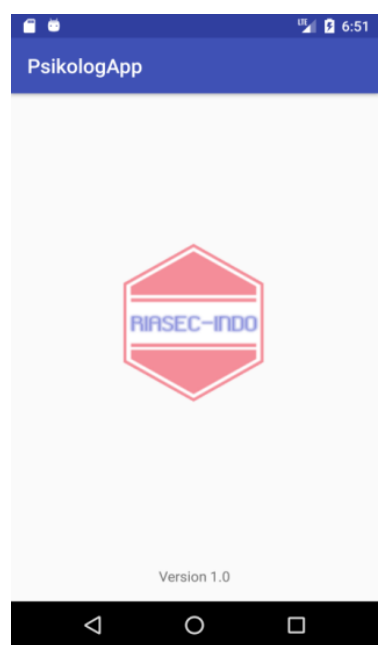

Figure 3. Splash Screen Interface in Psikologi Android Apps

The home page on android psychology is the first page that appears when it is signed into the opened application is opened. Figure 4 is the main view of home psychology android that can be accessed by visitors android psychology.

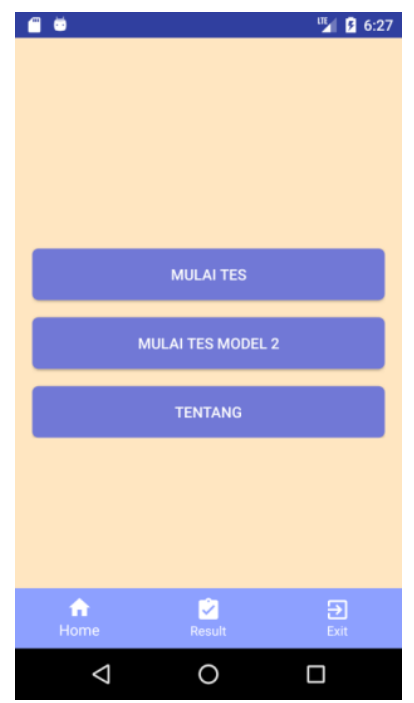

Figure 4. Homepage Psikologi Android Apps

KINETIK Vol. 3, No. 3, August 2018: 203-212 
This page is a display to start the test, there are 2 models used in this test, the first model there are 216 questions and the second model that there are 42 questions. Here is a look at the question on the first model shown in Figure 5.

\begin{tabular}{l} 
PsikologApp \\
Saya suka melakukan aktivitas ini \\
Memperbaiki alat-alat elektronik \\
(radio, amplifier, dsb) \\
Ya $\quad$ Tidak \\
Membaca buku-buku dan majalah \\
sains \\
Ya \\
Menulis dan membuat sketsa \\
Ya \\
\hline Menulis surat kepada teman/ \\
\hline Prev
\end{tabular}

Figure 5. List of Question Page in Professional Test Model

The second model consists of 42 questions, accessed through the main menu, the page in this application has a view identical to model 1, but the problems presented in the test amount is different. Figure 6 is the test view on the second model.

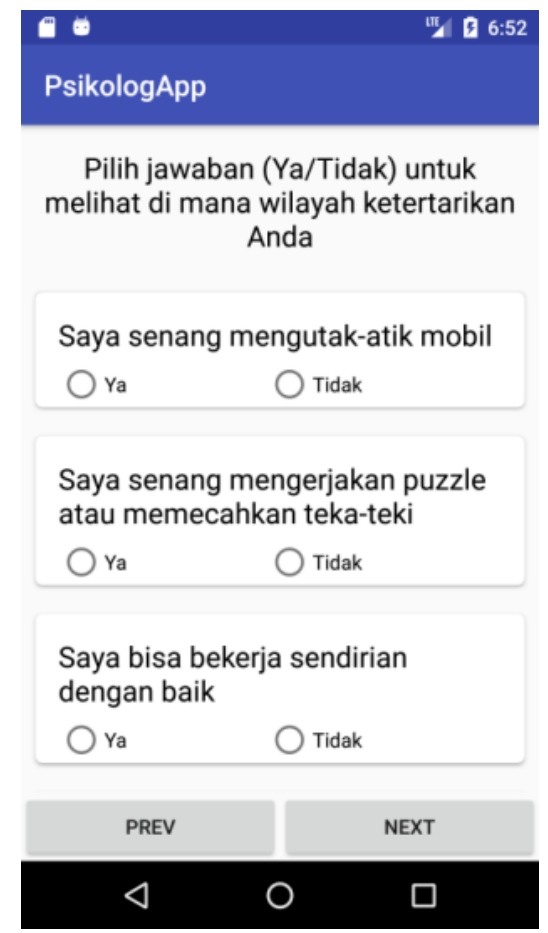

Figure 6. List of Question Page in General Test Model 
After the test is done, then the user can see the results of the tests performed. The following is the result of the display of the tests and recommendations resulting from the expert system shown in the Figure 7 and Figure 8.

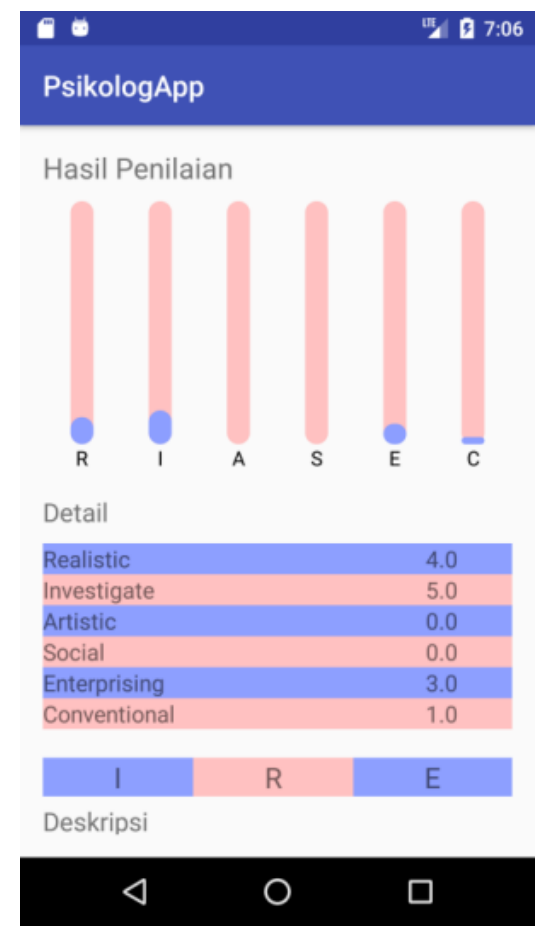

Figure 7. Result of Test Page in Android Application

\begin{tabular}{|c|c|}
\hline II/ $7: 06$ & II/ $18: 07$ \\
\hline PsikologApp & PsikologApp \\
\hline $\begin{array}{l}\text { Deskripsi } \\
\text { Bidang Ilmu: } \\
\text { Antropologi, Arkeologi,Kimia, Geofisika, } \\
\text { Geofisika, Teknik Geofisika ,Biologi, } \\
\text { Mikrobiologi, Bio-kimia, Fisika, } \\
\text { Matematika,Rekayasa Pertanian, Teknik } \\
\text { Pertanian, Teknik Pertanian, Teknologi } \\
\text { Industri Pertanian,Agroteknologi, } \\
\text { Teknologi Pangan, Teknologi Pangan } \\
\text { dan Hasil Pertanian,Ilmu Tanah,IImu } \\
\text { Hama dan Penyakit Tumbuhan, } \\
\text { Mikrobiologi, Rekayasa Hayati, } \\
\text { Rekayasa Pasca Panen, Teknologi } \\
\text { Perikanan, Arsitektur, Arsitektur Interior, } \\
\text { Teknik Mesin, Tenik Mesin,Teknik } \\
\text { Aeronautika, Teknik Material, Teknil } \\
\text { Metalurgi dan Material, Teknik Sipil, } \\
\text { Teknik Lingkungan, Teknik Kelautan, } \\
\text { Teknik Perkalapan, Tenik elektro, Teknik } \\
\text { Tenaga Listrik (Electrical Power } \\
\text { engineering), Teknik Informatika, Teknik } \\
\text { Komputer (computer engineering), }\end{array}$ & $\begin{array}{l}\text { Perguruan Tinggi: } \\
\text { UNPAD-Fakultas IImu Sosial dan Politik } \\
\text { UGM-Fakultas IImu budaya } \\
\text { UNPAD-FMIPA } \\
\text { ITB-FMIPA } \\
\text { UI-FMIPA } \\
\text { UIN SGD-FMIPA } \\
\text { UGM-FMIPA } \\
\text { UNPAD -FMIPA } \\
\text { UGM -FMIPA } \\
\text { ITB-FTTM } \\
\text { ITB-SITH } \\
\text { UGM -Fak. Teknologi Pertanian } \\
\text { UNPAD-Fak. Teknologi Industri Pertanian } \\
\text { UNPAD -Fak. Teknologi Industri } \\
\text { Pertanian } \\
\text { UGM-Fak. Teknologi Pertanian } \\
\text { UIN -Fak. Sains dan teknologi } \\
\text { UGM -Fak Pertanian } \\
\text { UGM-Fak Pertanian } \\
\text { UGM -Fak. Pertanian } \\
\text { ITB-SITH }\end{array}$ \\
\hline$\triangleleft$ & $\triangleleft$ \\
\hline
\end{tabular}

Figure 8. Recommendation Page in Psikologi Android Apps

Users can save the test results when the tests are done, so the history of test results can be seen again. Here is a view of the history of tests that have been done by the user in the Figure 9.

KINETIK Vol. 3, No. 3, August 2018: 203-212 


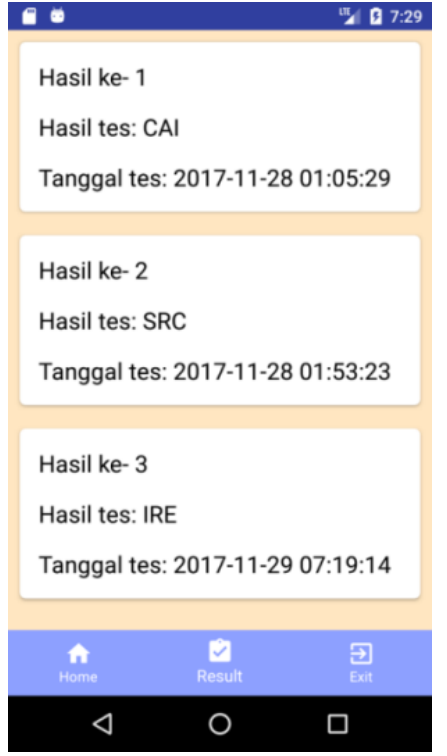

Figure 9. Showing History of Test Page in Psikologi Android Apps

\section{Conclusion}

The decision support system for the selection of study programs at universities is expected to be a tool to determine which courses are aligned with the characteristics of students. In this research, the application has already on Google Play Store as a helpful tool to recommend students in determining which majors you want to choose in universities [13]. The decision support system for the selection of study programs at the college provides information on the characteristics of the students so that it can help the counseling guidance counselors to assist in giving advice on the selection of study programs and to provide information and opportunities for high school students to explore themselves. It is expected that with self-exploration students can determine the appropriate choice related to study programs in college.

In order for the implementation of the system to run well, then some suggestions for further development include expanding the number of universities and major recommended, using additional criteria such as the value of student lessons will help in the selection of courses considering the new student. SNMPTN admission system is using the value from the test, as one of the selection criteria of university majors. In addition, it is also necessary to develop Internetbased applications so that there is a wider alternative to the choice of use for students.

\section{Acknowledgement} Bandung.

This study received funding from the DIPA managed by LP2M UIN Sunan Gunung Djat

\section{References}

[1] Y. Setyawan, "Sistem Pendukung Keputusan Pemilihan Program Studi dengan Metode Analytical Hierarchy Proses (AHP) di STAIN Kediri Berbasis Android," 2015.

[2] N. Wirastama, "Sistem Pendukung Keputusan Pemilihan Program Studi Pada Perguruan Tinggi Melalui Jalur SNMPTN Pada SMAN 16 Semarang," UDiNus Repository, 2013. [Online]. Available: http://eprints.dinus.ac.id/id/eprint/12717.

[3] B. B. Zwibelman and R. T. Plant, "Choosing a College Major: A Prototype Decision Support System," Computers in Human Behavior, Vol. 10, No. 3, Pp. 231-242, 1994.

[4] J. L. Holland, "Making Vocational Choices: A theory of Vocational Personalities and Work Environments, " Vol. 3. 1997.

[5] J. C. Smart, K. A. Feldman, and C. A. Ethington, "Holland's Theory and Patterns of College Student Success." Pp. 1-50, 2006.

[6] J. L. Holland, "A Psychological Classification Scheme for Vocations and Major Fields," Journal of Counseling Psychology, Vol. 13, No. 3, Pp. 278-288, 1966.

[7] G. D. Gottfredson, "John L. Holland's Contributions to Vocational Psychology: A Review and Evaluation," Journal of Vocational Behavior, Vol. 55, No. 1, Pp. 15-40, Aug. 1999. 
[8] Crowley and A. D., "Predicting Occupational Entry: Measured Versus Expressed Interests," Journal of Occupational Psychology, Vol. 56, No. 1, Pp. 51-61, 1983.

[9] E. Turban, J. E. Aronson, and T.-P. Liang, "Decision Support Systems and Intelligent Systems," Pearson/Prentice Hall, 2005.

[10] C. Brandaş, "Unified Approach in the DSS Development Process," Information Economics, no. 141, 2007.

[11] Kroll. Per and P. Kruchten, "Rational Unified Process Made Easy (03rd Edition)," AdisonWesley Profesional, 2003.

[12] B. Boehm, "Barry Boehm Software Engineering Economics," Vol. 10, No. 1. Prentice-hall, 1984.

[13] Fridayanti and W. Uriawan, "RIASEC-Indo." 2017.

KINETIK Vol. 3, No. 3, August 2018: 203-212 